\title{
PATHOLOGICAL AND PARASITOLOGICAL STUDIES ON SOME EIMERIA SPECIES IN RABBITS USING LIGHT AND ELECTRON MICROSCOPE
}

\author{
ABEER H.M. ELHENDY ${ }^{1}$; HUDA M. KURAA ${ }^{2}$ and BASEM R. NAGEIB ${ }^{3}$ \\ ${ }^{1}$ Pathology Department, Animal Health Research Institute, Assiut Governorate, Egypt \\ ${ }^{2,3}$ Parasitology Department, Animal Health Research Institute, Assiut Governorate, Egypt
}

Received: 31 March 2018; Accepted: 24 April 2018

\begin{abstract}
The prevalence of Eimeria in 50 examined rabbits was 84\% (42/50). The prevalence was $92.6 \%$ in male rabbits while it was $73.9 \%$ in female rabbits. According to age, the prevalence was determined $88 \%$ in rabbits less than 4 months of age while it was $80 \%$ in rabbits 4 months of age or more. No significant difference was recorded between rabbits in correlation to age and sex. Ten species of Eimeria infecting rabbits were isolated in Assiut by parasitological examination. The prevalence of Eimeria species were E. perforans (66.7\%) followed by E. exigua (26.2\%), E. media (26.2\%), E. magna (21.4\%), E. intestinalis (19\%), E. coecicola (19\%), E. irresidua (19\%), E. piriformis (14.3\%), E. flavescens (7.1\%) and E. stiedae (7.1\%). Single infection of Eimeria spp. was found in $23.8 \%$ of the infected rabbits, where as mixed infection involved two, three or four Eimeria spp. was observed in $76.2 \%$ of the infected rabbits. Clinical signs were depression, anorexia, diarrhea while postmortem examination revealed hepatomegaly with presence of separate yellowish-white nodules of varying sizes spread over the surface with distended gall bladder. The intestinal lesions revealed varying degree of congestion, thickening of intestinal wall. Histopathological examination of the liver revealed dilated bile ducts and formation of papilliform projections of epithelium containing different developmental stages of Eimeria, associated with degeneration and pathological changes in hepatic parenchyma. The intestinal coccidiosis revealed hyperplasia of the epithelial cells and presence of Eimeria oocytes and gametocytes within the epithelial cells of the villi associated with lymphocytic infiltration in the lamina propria of the villi. The transmission electron microscope showed asexual and sexual developmental stages of rabbit Eimeria including developing schizont and macrogametocyte.
\end{abstract}

Key words: Pathology, parasitology, light microscope, electron microscope, Eimeria species, rabbits.

\section{INTRODUCTION}

Rabbit meat is used as a good source of animal protein with low fat and cholesterol in Egypt as well as for medical and biological purposes (Ragheb et al., 1999 and Beal et al., 2004). Coccidiosis is amost common and highly contagious important parasitic disease in rabbits caused by Eimeria species (Shi et al., 2016). It occurs all over the world and is associated with high morbidity and mortality (Wessels et al., 2011; El-Shahawi et al., 2012 and Tao et al., 2017). Most of Eimeria spp. affect the rabbit production and constitutes a serious problem leading to major economic losses in rabbit farms including reduced growth rate and feed conversion and increased mortality according to their level of pathogenicity and its eradication is laborious (Vancraeynest et al., 2008 and Pakandl, 2009).

Corresponding author: Dr. BASEM R. NAGEIB

E-mail address: Abeerhashim_elhendy@yahoo.com;

Huda5380@yahoo.com; Basemnageib@gmail.com

Present address: Parasitology Department in Animal Health Research Institute, Assiut Governorate, Egypt
Clinical signs of coccidiosis in rabbits are diarrhea, loss of appetite, weight loss, dehydration, secondary sepsis and death. However, it is common that rabbits present subclinical forms of intestinal and hepatic coccidiosis, characterized by reduced feed intake and higher feed conversion ratio lead to a decline in body weight gain. All domesticated rabbit breeds can be infected by coccidia, specially the younger populations between 1 and 4 months of age (Bhat et al., 1996; Pakandl, 2009; Al-Quraishy et al., 2012 and Metwaly et al., 2013).

Eimeria species are highly host, organ and tissue specific (Levine, 1985). Eleven species of Eimeria infect rabbits: E. coecicola, $E$. flavescens, $E$. intestinalis, E. irresidua, E. exigua, E.magna, E. media, E. perforans, E. piriformis and E. vejdovskyi are the main species that cause intestinal coccidiosis in rabbits except $E$. steidae causes hepatic coccidiosis in the liver. Among these species, E. steidae, E. intestinalis and E. flavescens are highly pathogenic in rabbits, especially before the age of 3 months (Kvičerová et al., 2008; Pakandl, 2009; Oliveira et al., 2011 and Yan et al., 2013). 
Sporulated oocysts of Eimeria spp. invade rabbits which rupture, then sporozoites invade the intestinal, liver and bile duct epithelial cells where merogony occurs. Merozoites continue to increase until they complete four generations. At the gametogony stage, macrogametes and microgametes combine into zygotes and eventually develop into oocysts (Li and Ooi, 2009 and Oliveira et al., 2011). Eimeria species can invade and destroy intestinal cells of the hosts, causing anemia, electrolyte imbalance and poor absorption of nutrients (Szkucik et al. 2014 and Metwaly et al. 2013). While, Eimeria stiedae infects only the epithelial cells of the liver and bile ducts and causes huge liver damage with a variety of extremely disordered metabolic processes, increasing the secretion of toxins, diarrhea, slow growth and weight loss, and even causing the death of a large number of rabbits with a mortality rate as high as $80 \%$ after infection (Li and Ooi, 2009; Oliveira et al., 2011 and Abed and Yakoob, 2013).

There is a deficiency in information on rabbit coccidiosis in Assiut. So, this investigation was performed to recognize the natural prevalence and the species of rabbit Eimeria with regarding the parasitological and pathological aspects of the disease and correlate the presence of the parasite with sex and age.

\section{MATERIALS AND METHODS}

A total of 50 rabbits were collected randomly from markets from August 2017 to December 2017 from Assiut Governorate. These 30 rabbits were suffering from diarrhea and 20 were apparently healthy with age from 1-12 months. Fecal samples were collected directly from the rectum using sterile gloves and were transferred immediately to the laboratory and were kept at $4^{\circ} \mathrm{C}$ in a refrigerator until processing within 48 hours of arrival.

Parasitological Examination: Fecal examination was adopted for the presence of oocysts using light microscope by direct smear and concentration flotation technique: according to Soulsby (1982), using saturated salt solution for detection of Eimeria spp. oocysts.

Sporultion of Eimeria species oocysts: the positive fecal samples were sporulated using $2.5 \%$ potassium dichromate solution at room temperature with good aeration. Nonsporulated oocysts and sporulated oocysts size were measured using light microscope with a calibrated eye piece micrometer and the species determined by size, shape and morphological appearance (Soulsby, 1982 and Levine, 1985).

Gross pathological Examination: Necropsy procedures were performed according to Hussein (2008). Observation of both intestinal and hepatic coccidiosis was conducted through pathological examination of intestine and liver abnormalities.

Histopathology Preparation Method: The intestinal and liver lesions of each rabbit were sliced in the size of about $1 \mathrm{~cm} 3$ and immersed in $10 \%$ neutral formalin solution for histopathological and ultrastructural examination. Then dehydrated and embedded in paraffin wax. Serial 4-5 microns sections of paraffin embedded tissues were stained with Hematoxylin and eosin stain (H\&E) for light microscope examination according to (Kiernan, 2001).

Transmission electron microscopy: Tissue specimens were excised and fixed in $5 \%$ buffered glutaraldehyde and then washed in cacodylate buffer (0.1M, PH 7.2). Tissue specimens were post fixed in $1 \%$ osmium tetraoxide, dehydration in grades of ethanol alcohol series and embedded in Epon 812. Semithin sections were prepared for orientation and selection of representative tissue specimens and stained with $0.5 \%$ Toulidine blue according to Bancroft and stevans (1993). Ultrathin sections of (500-800 $\mathrm{A}^{\circ}$ ) were done using ultramicrotome then contrasted in uranyl acetate and lead citrate, and examined under a (Jeol, CX11) electron microscope in Electron Microscope unit, Assiut University.

Statistical analysis: The statistical package SPSS was used for data analyses and a value of $\mathrm{P}<0.05$ was considered significant difference in comparison (Jing et al., 2012).

\section{RESULTS}

The prevalence of Eimeria spp. in the examined rabbits was $84 \%$ (42/50). The prevalence of Eimeria spp. was $90 \%(27 / 30)$ in rabbits suffering from diarrhea while it was $75 \%(15 / 20)$ in apparently healthy rabbits. Concerning the sex, the prevalence of Eimeria spp. was $92.6 \%(25 / 27)$ in male rabbits while it was $73.9 \%(17 / 23)$ in female rabbits (Table 1). The prevalence of Eimeria spp. according to age was determined and it was $88 \%(22 / 25)$ in rabbits less than 4 months of age while it was $80 \%(20 / 25)$ in rabbits 4 months of age or more (Table 2). No significant difference of Eimeria prevalence was recorded between rabbits aged less than 4 months and rabbits 4 months of age or more and also no significant difference of Eimeria prevalence was observed between males and females.

Parasitological examination revealed that the isolated ten species of Eimeria in rabbits in Assiut were $E$. exigua, E. perforans, E. intestinalis, E. coecicola, E. media, E. flavescens, E. piriformis, E. irresidua, E. magna and E. stiedae. The prevalence of Eimeria species infecting rabbits were E. perforans $(66.7 \%)$ followed by E. exigua (26.2\%), E. media (26.2\%), E. magna (21.4\%), E. intestinalis (19\%), E. coecicola 
(19\%), E. irresidua (19\%), E. piriformis (14.3\%), E. flavescens $(7.1 \%)$ and E. stiedae (7.1\%). Very high significant differences of prevalence was detected between different Eimeria spp. (Figure1, 2 and Table 3). Single infection of Eimeria spp. was found in $23.8 \%$ of the infected rabbits, where as mixed infection involved two, three or four Eimeria spp. was observed in $76.2 \%$ of the infected rabbits. Very high significant differences of prevalence was recorded of mixed infection than single infection (Table 4).

The main clinical signs showed by the infected rabbits were depression, anorexia, diarrhea with soiling of hind quarters, emaciation, rough hair coat and distended abdomen. Jaundice was reported in one case. Postmortem examination revealed macroscopic lesions in eleven rabbit's liver which showed hepatomegaly with presence of separate yellowishwhite nodules of varying sizes spread over its surface and in the parenchyma. The liver textures were extremely coarse and felt relatively hard. The gall bladders were distended with thick dark green bile or were empty with thickened tortuous wall (Figure 3). The intestinal lesions revealed varying degree of general congestion, petechial hemorrhages, thickening of intestinal wall and some distended with gases.

Histopathological examination of the liver revealed dilated bile ducts as a result of extensive proliferation and hyperplasia of bile duct epithelium leading to formation of papilliform projections of epithelium into the lumen containing a number of different developmental stages of E. stiedae in addition there were sloughed biliary epithelial cells in the lumen of the duct (Figures 4, 5). The surrounding portal area showed congestion and dilatation of portal vein, fibrous connective tissue reaction and inflammatory cells infiltration. Most of the hepatic parenchyma around the peripheral areas showed degenerative inflammatory changes (Figure 4). Strands of connective tissue from the periportal areas were seen invading the hepatic parenchyma giving areas of pseudolobulation (Figure 5A). Other areas showed oocyte granuloma in which coccidial oocytes were surrounded by fibrous connective tissue infiltrated with mononuclear cells and even giant cells and hemorrhages (Figure 6).

Histopathological examination of the intestinal coccidiosis revealed different developmental stages of Eimeria in the intestinal epithelium including developing schizonts, macrogamytocytes, microgamytocytes and ovoid oocyst of Eimeria associated with lymphocytic infiltration in the lamina propria of the villi. The epithelial cells of villi showed a mild degree of hydropic degeneration and hyperplasia was observed with focal eosinophilic cellular reaction and some villi were edematous (Figure7). Morphologically macrogametocytes structures were oval to round and filled with large homogeneous, rounded, bright pink to bluish cytoplasmic granules (referred to as wall-forming bodies). Single large, centrally located nuclei occasionally were seen. Microgametocytes structures were large, round, and were filled with high numbers of purple, round to comma-shaped microgametes. Oocysts were ovoid to ellipsoidal, usually bright pink wall sometimes wrinkled by fixation and drying. These stages were present within intestinal epithelial cells and extracellularly as a result of rupture of the epithelial cells (Figures 7, 8).

The use of transmission electron microscope (TEM) allowed the identification of asexual and sexual developmental stages of Eimeria of rabbit. Examination of semithin section of intestine showed the appearance of the various coccidian stages as developing schizont and macrogametocyte (Figure 9). TEM showing schizogony of Eimeria, schizonts is multinucleated and contain wall forming bodies and veil forming bodies with amylopectin granules and lipid droplet. A cross-sectioned in developing multinucleated schizont in a parasitophorous vacuole contains mitochondria and surrounded by plasma cells (Figure 10). Also, it revealed developing macrogametocytes (Early to mid-stage) surround by a parasitophorous vacuole in host cell. It possesses a nucleus and cytoplasm contains some areas of dilated rough endoplasmic reticulum designated as early wall forming bodies and veil forming bodies. Early parasite phagocytosis found as host phagocytic cell engulfed the parasite and surrounded by plasma cell and large number of host mitochondria indicating host defense mechanism (Figure 11).

Table 1: Effect of health status and sex on the prevalence of Eimeria spp. in rabbits

\begin{tabular}{ccccc}
\hline & Health status/Sex & No. of examined rabbit & No. of positive samples & $\%$ \\
\hline \multirow{2}{*}{$\begin{array}{c}\text { Health } \\
\text { status }\end{array}$} & Diarrhea & 30 & 27 & 90 \\
\cline { 2 - 5 } Sex & Apparently healthy & 20 & 15 & 75 \\
\cline { 2 - 5 } & Male & 27 & 25 & 92.6 \\
\hline
\end{tabular}

Insignificant differences $(\mathrm{P}>0.05)$ 
Table 2: Effect of age on the prevalence of Eimeria spp. in rabbits

\begin{tabular}{lccc}
\hline Age & No. of examined rabbit & No. of positive samples & $\%$ \\
\hline$<4 \mathrm{~m}$ & 25 & 22 & 88 \\
\hline$\geq 4 \mathrm{~m}$ & 25 & 20 & 80 \\
\hline Total & 50 & 42 & 84 \\
\hline
\end{tabular}

Insignificant differences $(\mathrm{P}>0.05)$

Table 3: Morphological characteristics of ten Eimeria species isolated from infected rabbits with its prevalence rates $(\%)$

\begin{tabular}{lccccccc}
\hline $\begin{array}{c}\text { Eimeria species } \\
* * *\end{array}$ & $\begin{array}{c}\text { No. of } \\
\text { infected } \\
\text { rabbits }\end{array}$ & $\begin{array}{c}\text { Total } \\
\text { infected }\end{array}$ & $\%$ & Shape & Size $(\mu \mathrm{m})$ & Micropyle & Residuum \\
\hline E. perforans & 28 & 42 & 66.7 & Ellipsiodal & $27.31 \times 17.09 \mu$ & not visible & present \\
\hline E. exigua & 11 & 42 & 26.2 & Sub-spherical & $18.98 \times 16.09 \mu$ & not visible & no \\
\hline E. media & 11 & 42 & 26.2 & Ellipsiodal & $34.58 \times 18.98 \mu$ & visible & Present \\
\hline E. magna & 9 & 42 & 21.4 & Ovoidal & $36.31 \times 25.73 \mu$ & visible & present \\
\hline E. intestinalis & 8 & 42 & 19 & Pyriform & $31.23 \times 18.86 \mu$ & visible & present \\
\hline E. coecicola & 8 & 42 & 19 & Ovoidal & $30.19 \times 19.67 \mu$ & visible & present \\
\hline E. irresidua & 8 & 42 & 19 & Ovoidal & $35.07 \times 22.13 \mu$ & visible & no \\
\hline E. piriformis & 6 & 42 & 14.3 & Pyriform & $32.79 \times 22.73 \mu$ & visible & no \\
\hline E. flavescens & 3 & 42 & 7.1 & Ovoidal & $31.01 \times 22.38 \mu$ & visible & no \\
\hline E. stiedae & 3 & 42 & 7.1 & Ovoidal & $34.17 \times 21.71 \mu$ & visible & no \\
\hline
\end{tabular}

*** Very high significant differences $(\mathrm{P}<0.0001)$

Table 4: Prevalence of single and mixed infection of Eimeria species in infected rabbits

\begin{tabular}{ccccc}
\hline \multirow{2}{*}{ Total positive } & \multicolumn{2}{c}{ Single infection } & \multicolumn{2}{c}{ Mixed infection*** } \\
\hline \multirow{2}{*}{42} & No. & $\%$ & No. & $\%$ \\
\cline { 2 - 5 } & 10 & 23.8 & 32 & 76.2 \\
\hline
\end{tabular}

$* * *$ Very high significant differences $(\mathrm{P}<0.0001)$ 


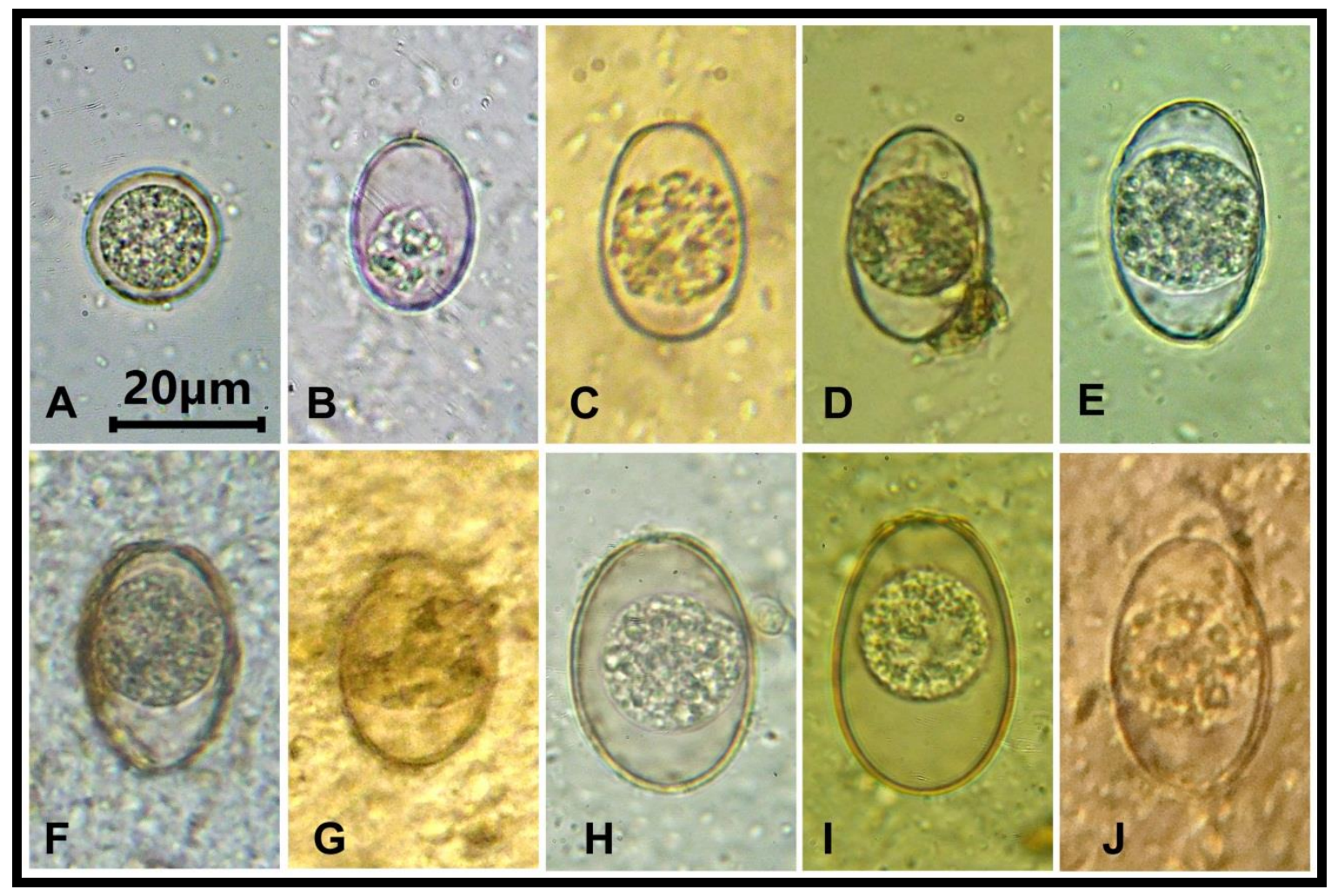

Figure (1): Unsporulated oocysts of the ten Eimeria spp. from naturally infecting rabbits (A) Eimeria exigua (B) E. perforans (C) E. intestinalis (D) E. coecicola (E) E. media (F) E. flavescens (G) E. piriformis $(\mathrm{H})$ E. irresidua (I) E. magna (J) E. stiedae

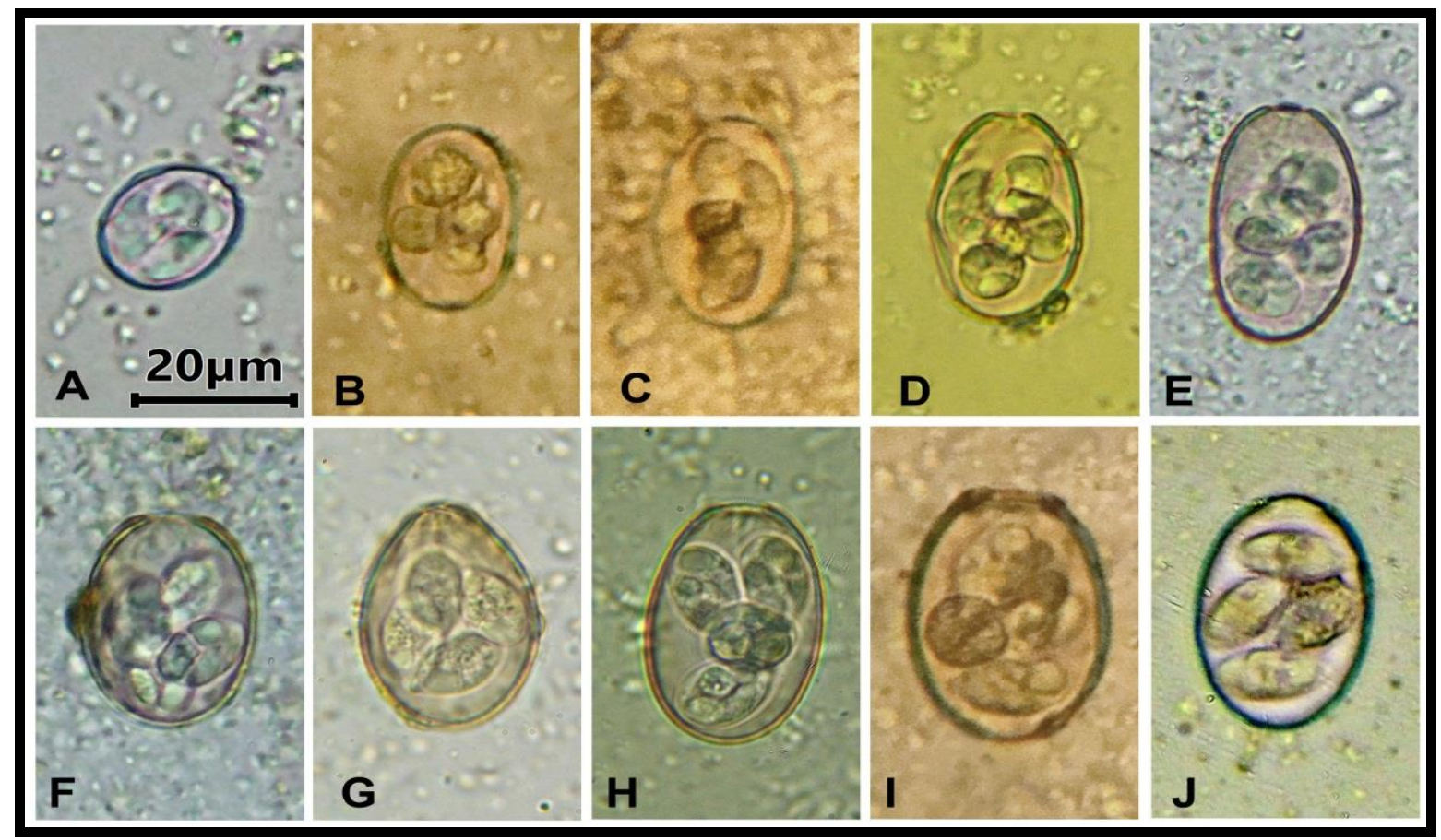

Figure (2): Sporulated oocysts of the ten Eimeria spp. isolated from naturally infecting rabbits (A) Eimeria exigua (B) E. perforans (C) E. intestinalis (D) E. coecicola (E) E. media (F) E. flavescens (G) E. piriformis (H) E. irresidua (I) E. magna (J) E. stiedae 


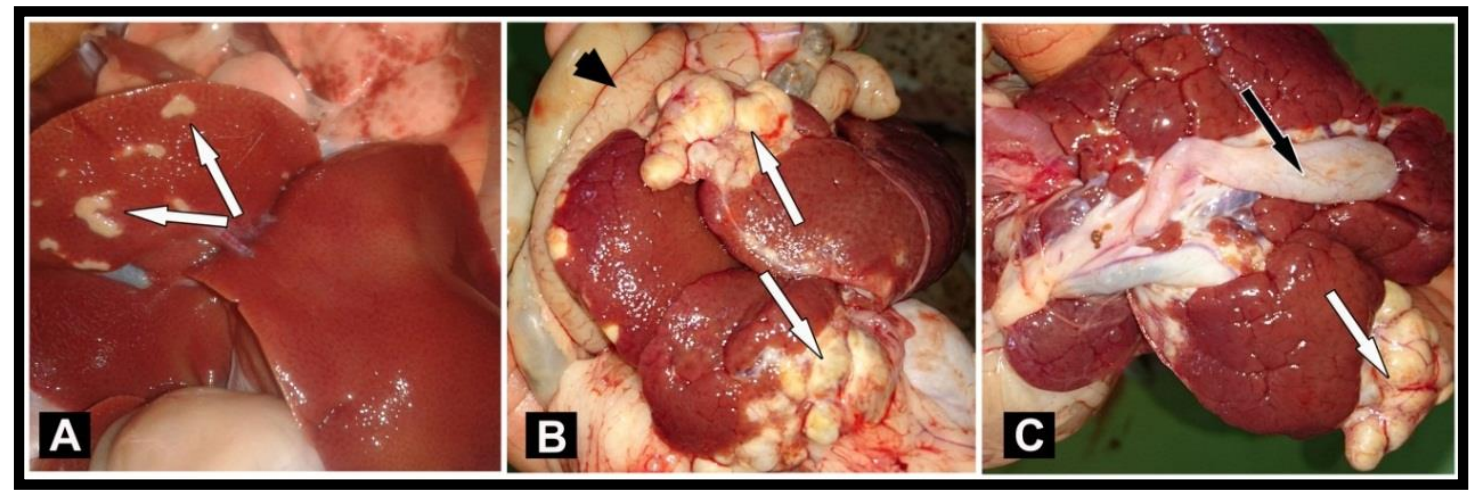

Figure (3): Gross lesion in the liver of rabbit infected with E. stiedae showing irregular yellowish white nodules of varying sizes on the surface (white arrow) and dilated empty gall bladder (black arrow). Thickening of intestinal wall and some distended with gases (black arrow head).

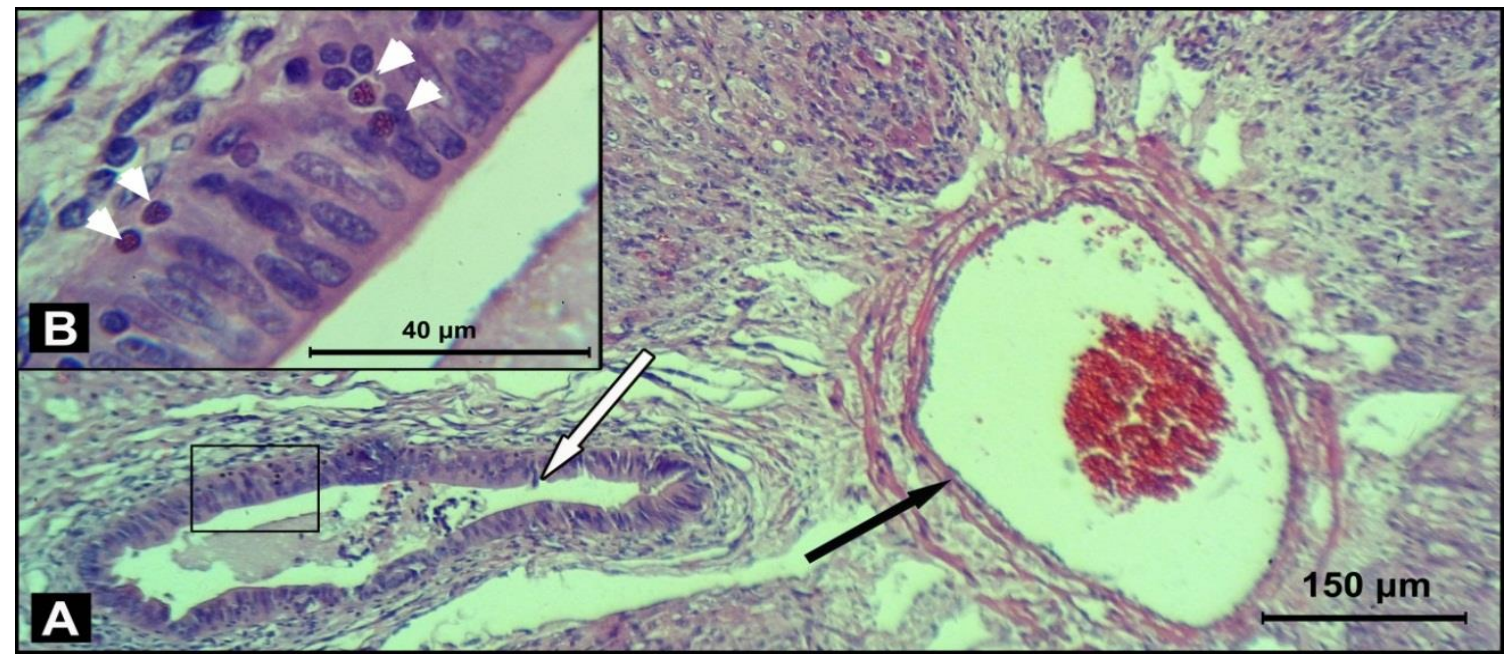

Figure (4): Histopathological section of a rabbit liver affected with coccidiosis. A: showing congested and dilated portal vein (black arrow) surrounded by fibrous connective tissue and infiltrated with inflammatory cells. Hyperplasia of the epithelial cells of the billary duct (white arrow) (X 100). B: high magnification of the square section of the hyperplasia epithelial cells of the billary duct showed developing schizonts of the Eimeria stidae (white arrow head) H\&E (X 1000).

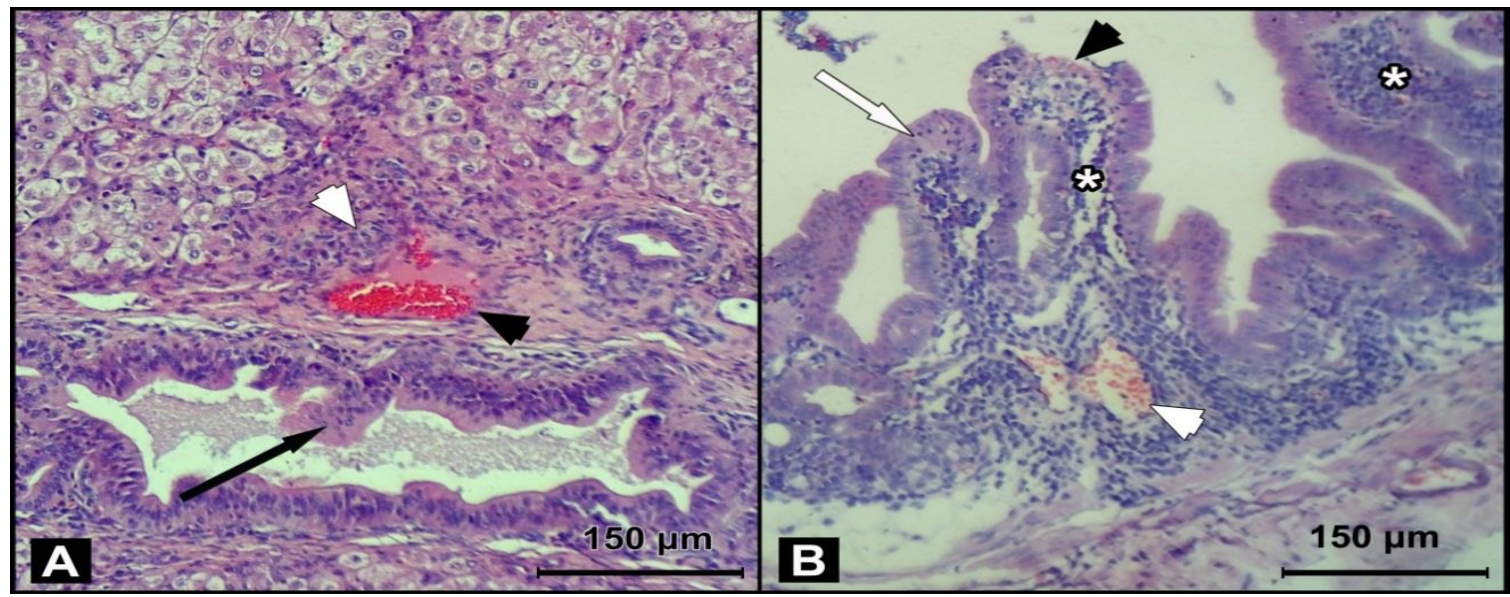

Figure (5): Histopathological section of a rabbit liver affected with coccidiosis. A: showing hyperplasia of the epithelial cells of the billary duct (black arrow) congested portal vein (black arrow head) with mononuclear cells infiltration and hemorrhages (white arrow head) (X 100). B: showing hyperplasia of the bile duct forming papillary fronds projecting into the dilated ductal lumen (white arrow) with sloughing of epithelial cells (black arrow head) and infiltrated with inflammatory cells (astresik) with congested blood vessel (white arrow head) (H\&E stain) (X 100). 


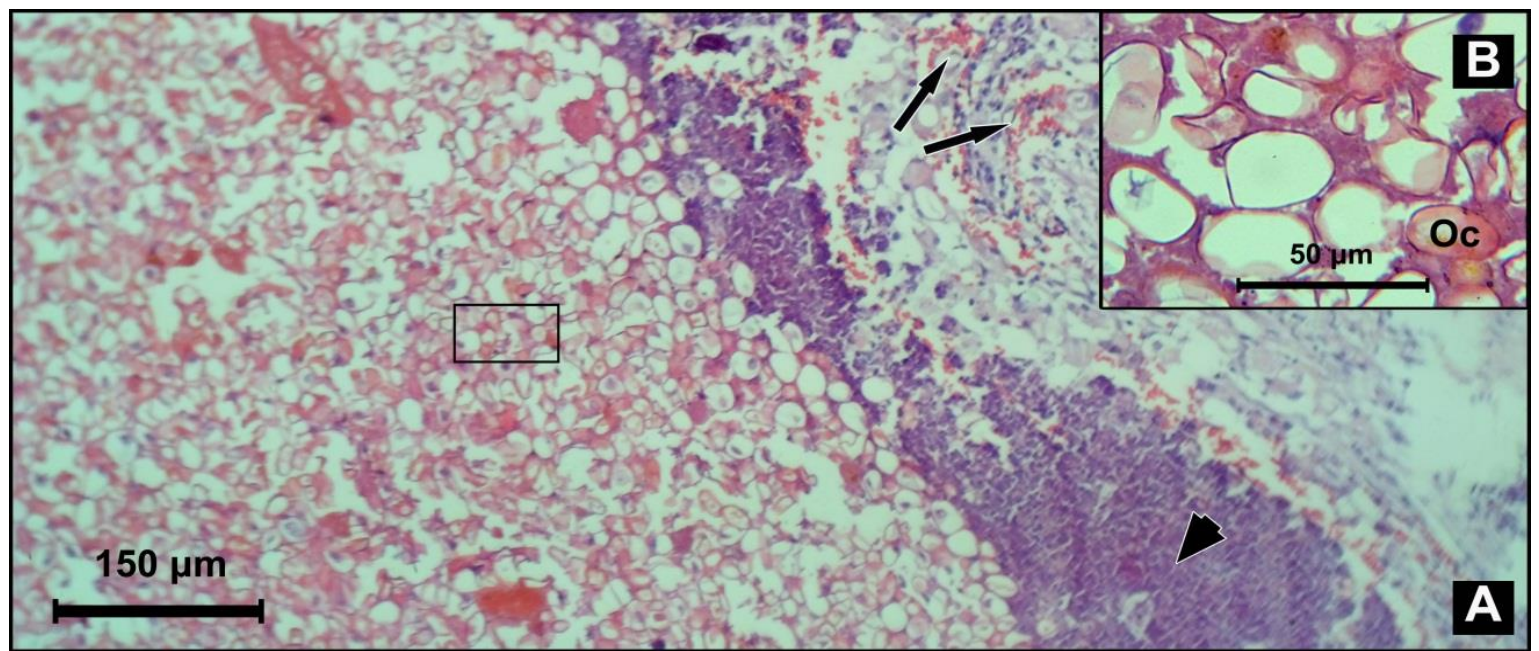

Figure (6): Liver affected with coccidiosis. A: showing oocyst granuloma within hepatic parenchyma surrounded by fibrous tissue and infiltrated with inflammatory cells "macrophages, lymphocytes, eosinophils and giant cell" (arrow head) and there is hemorrhage (arrows) at the periphery (X100). B: high magnification of the square section of the oocyst (Oc) granuloma. (H\&E) (X 1000).

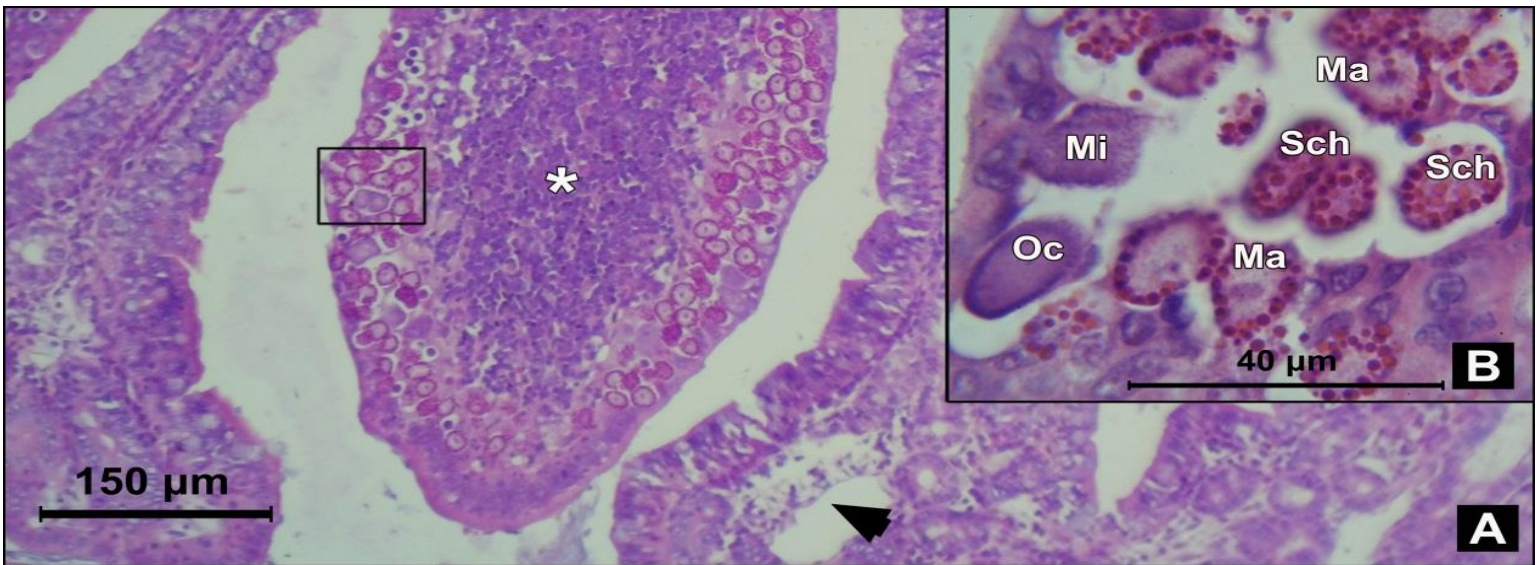

Figure (7): Intestine with coccidiosis. A: showing different developmental stages of Eimeria in the intestinal epithelium, lymphocytic infiltration in the lamina of the villi (asterisk) and edema (arrow head) (X 100). B: high magnification of the square section showing presence of numerous stages including developing schizonts (Sch), macrogamytocytes (Ma), microgamytocytes (Mi) and oocyst (Oc) of Eimeria (H\&E) (X 1000).

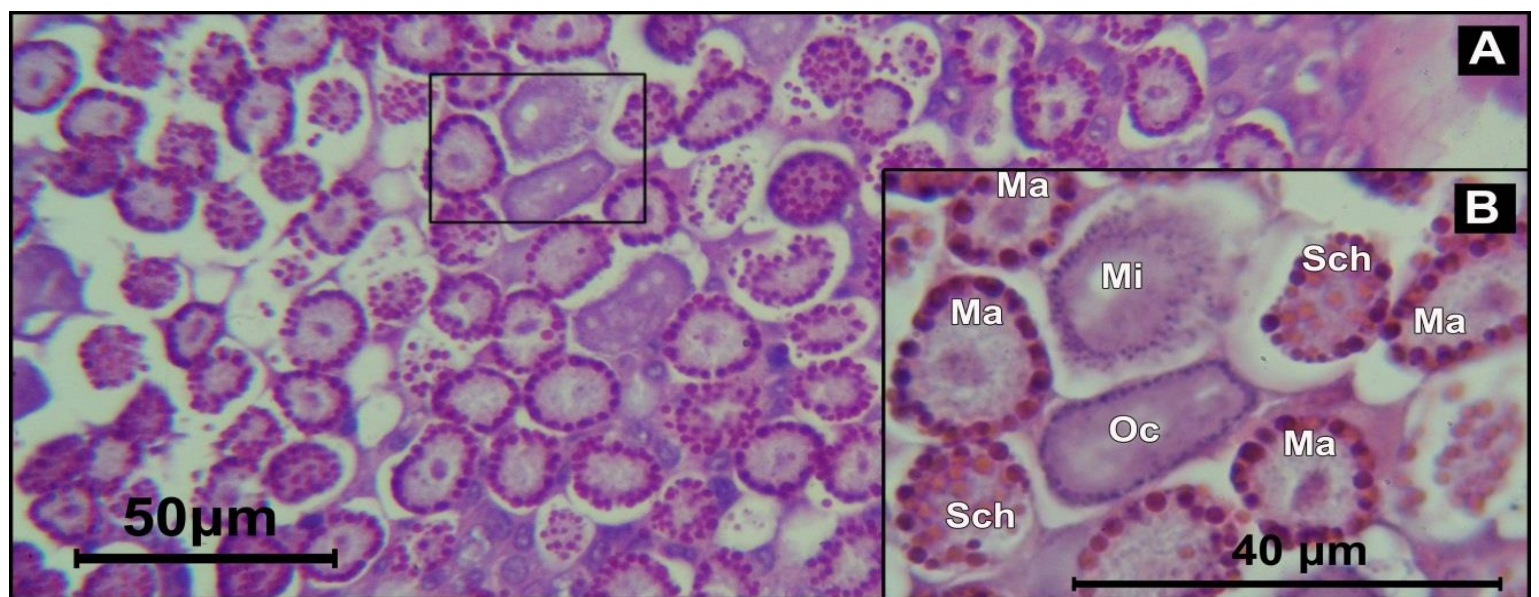

Figure (8): Intestine. A: showing different developmental stages of Eimeria in the intestinal epithelium (X 400). B: high magnification of the square section showing different developmental stages include developing schizont (Sch), macrogamytocytes (Ma) microgamytocytes (Mi), and oocyst (Oc) of Eimeria (H\&E) (X 1000). 


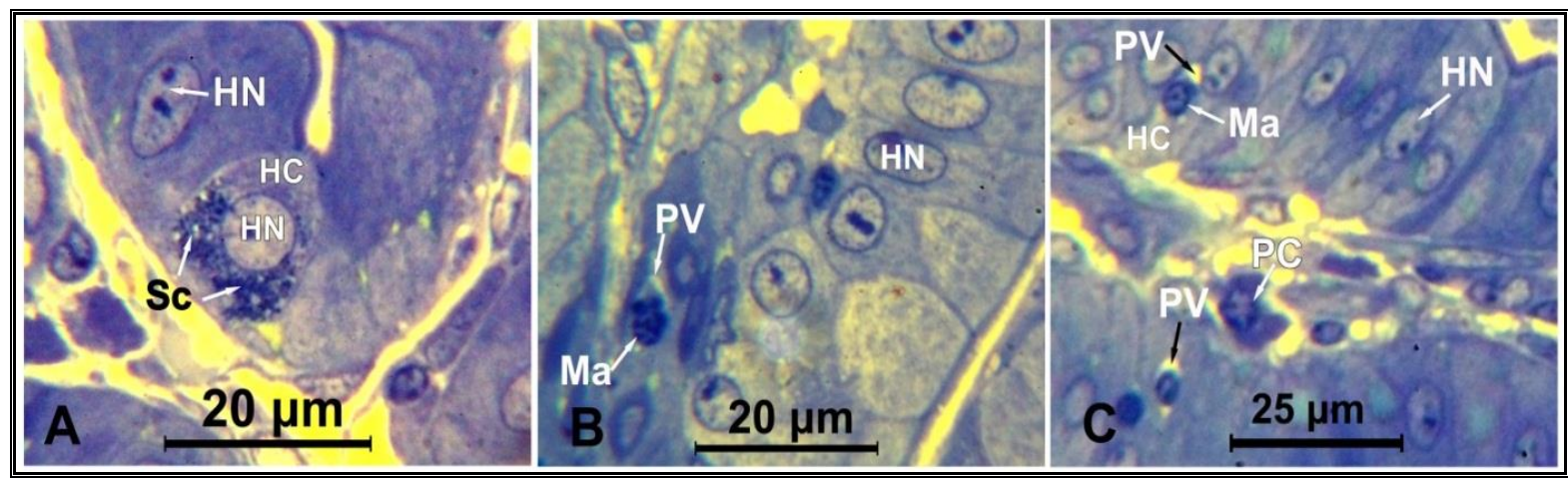

Figure (9): Semithin sections of the rabbit intestine showing the appearance of the various coccidian stages (both asexual and sexual) stained with Touildine blue. A: revealed developing schizont (Sc) in host cell (HC) beside host nucleus (HN) (X1000).B showing macrogametocyte (Ma) surrounded by parasitophorous vacuole (PV) in host cell beside host nucleus (HN) (X 1000). C: showing macrogametocyte (Ma) surrounded by parasitophorous vacuole (PV) in host cell (HC) beside host nucleus (HN). Note plasma cell (PC) in the lamina propria (X 400).

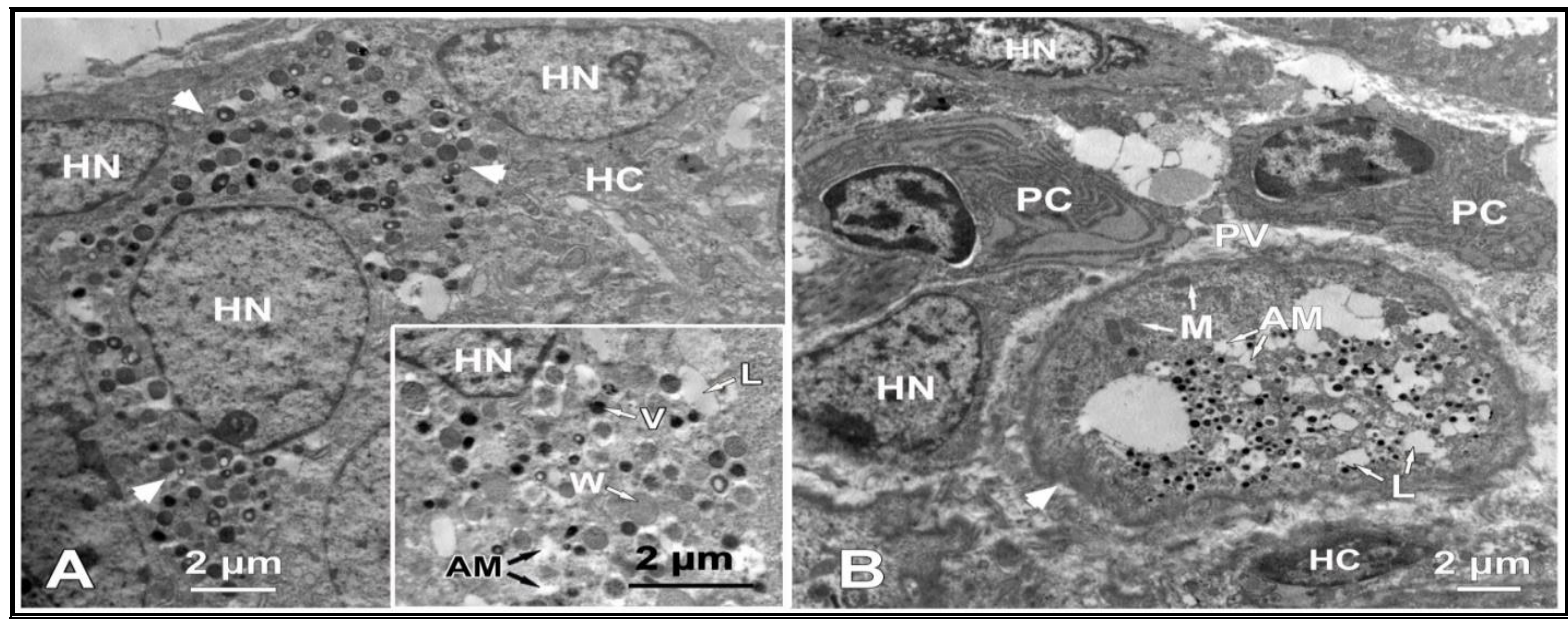

Figure (10): Transmission electron micrograph (TEM) showing schizogony of Eimeria in intestine of rabbit. A: showing the developing schizonts (arrow head) inside host cell (HC) beside host nucleus (HN). Square show high magnification of schizonts which is multinucleated and contain wall forming bodies (W) and veil forming bodies (V) with amylopectin granules (AM) and lipid droplet (L) (X4800). B: A cross-sectioned in developing multinucleated schizont (arrow head) in a parasitophorous vacuole (PV) and contain amylopectin granules (AM) with lipid droplet (L) and mitochondria (M). Schizont surrounded by host cell (HC) contains host nucleus (HN) and plasma cells (PC) (X3600).

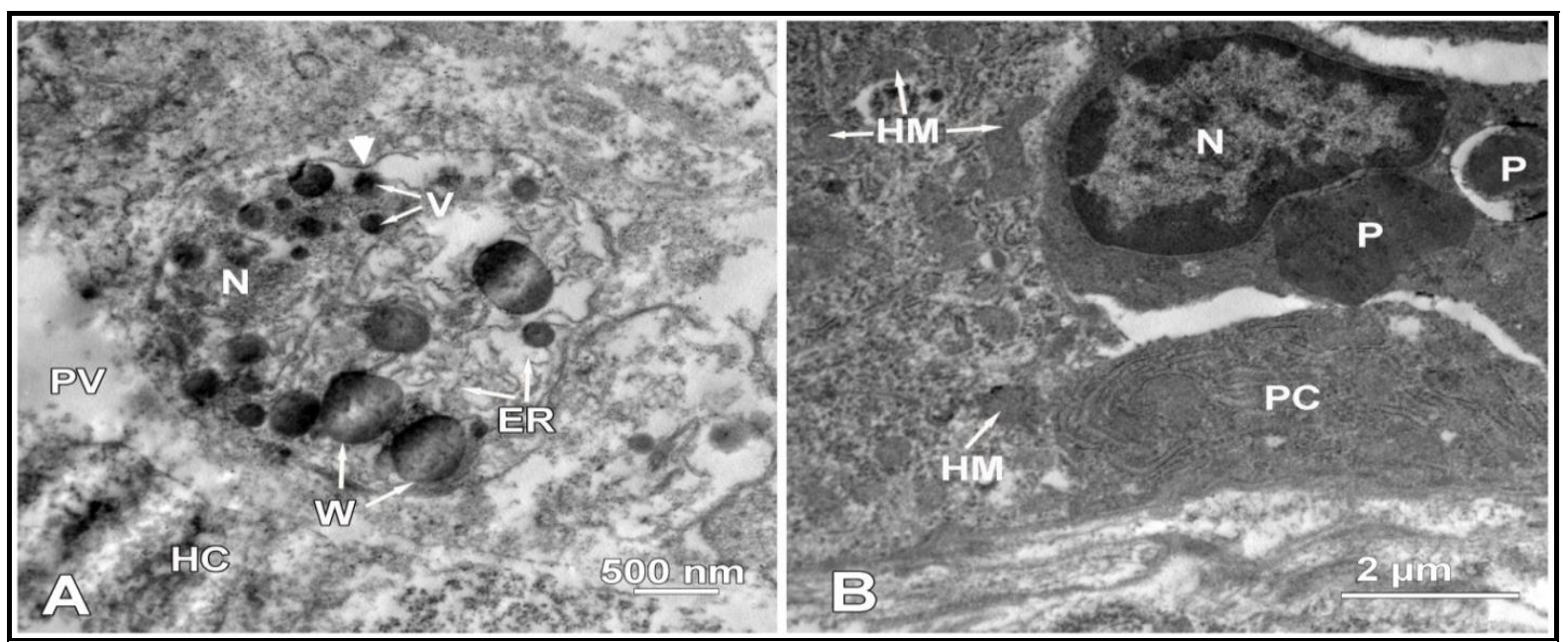

Figure (11): TEM of Eimeria in intestine of rabbit. A: showing the ultrastructural appearance of the developing macrogametocyte (Early to mid-stage) (arrow head) surround by a parasitophorous vacuole (PV) in host cell (HC). It contain a nucleus $(\mathrm{N})$ and the cytoplasm which contains some areas of dilated rough endoplasmic reticulum (ER) designated as early wall forming bodies (W) and veil forming bodies (V) (X19000). B: showing early parasite phagocytosis, macrophage contains nucleus $(\mathrm{N})$ and parasite $(\mathrm{P})$ and surrounded by plasma cell (PC) and large number of host mitochondria (HM) (X10000). 


\section{DISCUSSION}

Coccidiosis remains one of the most important infectious causes of digestive disorders in fattening rabbits (Vancraeynest et al., 2008). The strong fecundity and prolonged resistance of Eimeria to the hostile environment are responsible for the wide prevalence, such that nearly all rabbits are affected (Lebas et al., 1997 and Jing et al., 2012).

In the present study, the overall prevalence of Eimeria spp. was observed in 84\% (42/50) of the samples. The obtained result was in line with Qiao et al. (2012) and Okumu et al. (2014) who reported high occurrence of Eimeria spp. in rabbits $(78.11 \%$ and $85.1 \%$ ) in Northwest China and Kenya, respectively. In contrast, both Song et al. (2012) and BalickaRamisz et al. (2014) showed that the prevalence of infection in rabbit was $100 \%$ in China and Poland, respectively. While previous reports in Egypt showed lower prevalence rates of coccidiosis such as, ELMasry (1983) $57.3 \%$ in Dakahllia governorate; Abdalla (1988) $72 \%$ in Assiut governorate; Ibrahim (1990) $65.8 \%$ in Giza governorate and (El-Shahawi et al., 2012) $70 \%$ in Beni-Suef governorate. This variation in infection rates is explained by the difference in environmental conditions prevailing in each region such as increase humidity, optimum temperature favoring the sporulation of oocysts, he rearing conditions, the system of housing of rabbits was battery or ground breeding systems, the use of chemoprophylaxis, type of feeding as well as the number of samples examined (Al-Mathal, 2008; Abdel-Baki and Al-Quraishy 2013; Mohammed et al., 2013; Laha et al., 2015 and Yin et al., 2016).

Our studies revealed that 10 species of Eimeria were identified in 50 fecal samples of domestic rabbits, namely E. Perforans, E. media, E. magna, E. exigua, E. irresidua, E. intestinalis, E. coecicola, $E$. piriformis, E. flavescens and E. stiedae. In previous studies undertaken in Egypt, in Assuit governorate Abdalla (1988) recognized 5 species of Eimeria oocysts (E. Perforans; E. media; E. irresidua; E. magna and E. stiedae), while Ibrahim (1990) collected 4 species of Eimeria (E. stiedae, $E$. coecicola, E.perforans and E. intestinalis) in Giza governorate. Moreover, El-Shahawi et al. (2012) detected 8 species of Eimeria (E. stiedae, Eimeria media, E. intestinalis, Eimeria coecicola, E. magna, Eimeria exigua, Eimeria perforans and Eimeria flavescens) in Beni-Suef governorate.

Postmortem examination revealed macroscopic irregular yellowish white nodules of varying sizes lesions in eleven rabbit's liver while microscopic examination of its fecal samples revealed E. stiedae oocyst in 3 rabbits only. Our results revealed small liver lesions with no oocysts of E. stiedae. This may due to recent infection as explained by (Smetena, 1933 and Barriga and Arnoni, 1981) who recorded long prepatent period of E. stiedae with first oocystic shedding at the 3 rd to the 4 th week after infection. Also, (Hassan et al., 2016) recorded peak of oocyst shedding at 25 days after infection, then began to decline.

It was noticed that, E. perforans was the most prevalent species $(66.7 \%)$, followed in order by $E$. media, E. exigua, E. magna, E. irresidua, E. coecicola and E. intestinalis with prevalences of $26.2 \%, 26.2 \%, 21.4 \%, 19 \%, 19 \%$ and $19 \%$, respectively. while prevalence of $E$. piriformis, $E$. stiedae and E. flavescens were $14.3 \%, 7.1 \%$ and $7.1 \%$, respectively with high significant variations were noticed $(\mathrm{p}<0.0001)$. These results agreed with Abdalla (1988) who mentioned that the prevalence of E. Perforans; E. media; E. irresidua; and E. magna was $47.3 \%, 41.3 \%, 21.6 \%$ and $18.4 \%$ in Assuit governorate, respectively. Moreover in Saudi Arabia; Toula and Ramadan (1998) found that the most common species were E. perforans (65\%), E. magna (45\%), E. stiedae (25\%), E. exigua (20\%) and E. piriformis (10\%). In France Grès et al. (2003) declared that the predominant species was $E$. perforans $(87 \%)$, E. media $(55 \%)$ and E. magna (53\%), respectively. Similarly, in China Jing et al. (2012) mentioned that E. perforans was the most prevalent species $(35.2 \%)$, followed by $E$. media (31.3\%), E. magna (28.8\%), E. irresidua (19.4\%) and E. intestinalis (14.8\%).

Mixed infections are common and generally, more than one species of Eimeria often parasitize the intestinal epithelium of rabbits (Toula and Ramadan, 1998). In our study, high significant differences between mixed and single infection ( $p<0.0001)$ where mixed infection with two species or more was most frequently occurring $(76.2 \%)$ while infection with single species is rarely occurring (23.8\%), these are agreed with the results of previous reports in Egypt and other countries (El-Shahawi et al., 2012; Qiao et al., 2012 and Abdel-Baki and Al-Quraishy, 2013). The consequences of these conditions could result in overwhelming diseases that may coincide with economic losses in rabbit rearing industries (Razavi et al., 2010).

Higher prevalence was recorded among young individuals ( $<4$ months) than adults ( $\geq 4$ months) $88 \%$ and $80 \%$, respectively with no statistical significance $(\mathrm{P}>0.05)$. The difference in prevalence among young and adult animals had already been reported in Taiwan, China and Brazil (Ming-Hsien et al., 2010; Yin et al., 2016 and Heker et al., 2017) $(53.6 \%, 31.2 \%) ;(45 \%, 42 \%)$ and $(46.67 \%, 14.81 \%)$, respectively. The high level of susceptibility of infection in young rabbits may be due to lower resistance or less immunity to coccidian oocysts in 
young rabbits compared to elder animals (Al-Mathal, 2008 and Yin et al., 2016).

It was noticed that in males have higher prevalence $(92.6 \%)$ than females $(73.9 \%)$, with no significant difference $(\mathrm{P}>0.05)$. These results disagreed with Razavi et al. (2010) who found higher prevalence among females $63.7 \%$ than males $36.3 \%$. However, Khider et al. (2015), Ming-Hsien et al. (2010) and Heker et al. (2017) found no significant difference in the prevalence of Eimeria between male and female rabbits.

Macroscopic observations in this study are in agreement with previous report, in which the infected liver showed hepatomegaly, pale color and multiple scattered yellowish white nodules of variable sizes (AL-Naimi et al., 2012). Additionally, the gall bladder may also be enlarged and contain exudates (Pakes and Gerrity, 1994). Moreover, there was a distended empty gall bladder with thickened tortuous wall was observed in chronic case of hepatic coccidiosis which could be the result of granulomatous hepatitis and stasis of bile due to biliary obstruction by proliferation of bile duct epithelium along with massive number of oocysts within the bile duct lumen results in obstructive jaundice (Erdogmus and Eroksuz, 2006).

Histologically, bile ducts showed dilatation and extensive proliferation of the billiary epithelium accompanied with lymphoplasmacytic infiltration. Various developmental stages of E. stiedae were noticed in the biliary epithelium. Oocysts could be seen obstruct the lumen. Rupture of enlarged bile ducts results in asevere granulomatous response, while compression of adjacentliver parenchyma results in ischemic hepatic necrosis and gradually replaced by fibrous connective tissue (Erdogmus and Eroksuz, 2006 and Al-Mathal, 2008). The remarkable macroscopic observation in the intestine of infected animals was hyperemia of the infected parts of intestine and in other cases there was thickening of the wall appeared like white streaks. Microscopic result is in accordance with Abdalla (1988) who noted that intestinal coccidiosis usually occurs as mild infection where, the epithelial cells showed mild degree of hydropic degeneration with focal eosinophilic cellular reaction and some of the villi were edematous. However Baker (1998) described the changes in infected intestinal segments include epithelial necrosis, mucosal ulceration, congestion, edema and occasionally hemorrhages, villous atrophy and leukocytic exudate. Different developmental stages of Eimeria were noticed in the intestinal epithelium. Similar results were observed by Yakhchali and Tehrani (2007) who suggested that intestinal coccidiosis causes atrophy of the enterocytes lining the villi results in interference with intestinal function and impairs intestinal motility.
Ultrastructurally, in general, the exact number of the endogenous merogenic generations among the genus Eimeria is not fixed (Dai et al., 2005). After a specific number of merogonic generations, the merozoites develop into either macrogamonts and/or microgamonts (Hammond, 1973). In the present study, various coccidian stages (both asexual and sexual) were recognized including developing schizont and macrogametocyte characterized by the peripherally arranged wall-forming bodies and surrounded by parasitophorous vacuole were noted within the epithelial cell, even in the lamina propria of villi. These results are in accordance with those reported for many other Eimeria (Abdel-Ghaffar et al., 1991; Dai et al., 2005; Mehlhorn, 2006 and Bashtar et al., 2010). Additionally, there were plasma cells and macrophage phagocyte early parasite were observed, this may occurs as inflammatory defense reaction against Eimeria parasite.

\section{CONCLUSION}

In conclusion, we identified 10 species of Eimeria in rabbit in Assiut, with the presence of high prevalence of infections with multiple Eimeria species in the same animal. In addition we found that Eimeria in rabbits caused significant pathological lesions in liver, bile duct and intestine especially in young ages. Results of this study can help the understanding of disease occurrence to design effective control scheme for rabbit coccidiosis in the area.

\section{REFERENCES}

Abdalla, S.M.A. (1988): Studies on Endoparasities of Rabbits in Assiut. M.V.Sc (Parasitology) Thesis, Faculty of Medicine, Assiut University. Abdel-Baki, A.A.S. and Al-Quraishy, S. (2013): Prevalence of Coccidia (Eimeria spp.) infectionin Domestic Rabbits, Oryctolagus cuniculus, in Riyadh, Saudi Arabia. Pakistan Journal of Zoology, 45(5): 1329-1333.

Abdel-Ghaffar, F.A.; Bashtar, A.R.; Mustafa, A.M. and El Touky, A. (1991): Eimeria arvicanthi Van Den Berghe \& Chardome, 1956 and $E$. mehlhorninov. sp. infecting field rat Arvicanthus niloticus niloticus in Egypt. Arch Protistenkd. 140, 185-190.

Abed, H.H. and Yakoob, A.Y. (2013): Study of the protective and therapeutic effect of crude garlic on mortality, oocyst output and hepatic lesions in experimentally infection with Eimeria stiedae in domestic rabbits. Bas. J. Vet. Res. 12 (2): 314-331.

Al-Quraishy, S.; Metwaly, M.S.; Dkhil, M.A.; AbdelBaki, A.A. and Wunderlich, F. (2012): Liver response of rabbits to Eimeria coecicola infections. Parasitology Research 110: 901911. 
Al-Mathal, E.M. (2008): Hepatic Coccidiosis of the Domestic Rabbit (Oryctolagus cuniculus domesticus L.) in Saudi Arabia. World Journal of Zoology, 3(1): 30-35.

AL-Naimi, R.A.; Khalaf, O.H.; Tano, S.Y. and AlTaee, E.H. (2012): Pathological study of Hepatic coccidiosis in naturally infected rabbits. AL-Qadisiya Journal of Vet. Med. Sci. 11(1): 63-69.

Baker, D.G. (1998): Natural Pathogens of Laboratory Mice, Rats, and Rabbits and Their Effects on Research. Clinical Microbiology Review, 11(2): 231-166.

Balicka-Ramisz, A.; Wróbel, M. and Adadynska, K. (2014): Epidemiology and economic benefits of treating rabbits coccidiosis in small farms from West Pomerania province, Poland. Annals of parasitology, 60(4): 247251.

Bancroft, J.D. and Stevens, A. (1993): Theory and practice of histological techniques. 3rd ed. Churchill Livingstone. Edinburgh, London, Melbourne and New York.

Barriga, O.O. and Arnoni, J.V. (1981): Pathophysiology of hepatic coccidiosis in rabbits. Vet. Parasitol. 8 (3), 201-210.

Bashtar, A.; Abdel-Ghaffar, F.; AL-Rasheid, K.A.S.; Mehlhorn, H. and Al Nasr, I. (2010): Light microscopic study on Eimeria species infecting Japanese quails reared in Saudi Arabian farms. Parasitol. Res. 107, 409-416.

Beal, M.N.; McLean-Meyinsse, P.E. and Atkinson, C. (2004): An Analysis of Household Consumption of Rabbit Meat in the Southern United States. Journal of Food Distribution Research 35(1): 24-29.

Bhat, T.K.; Jithendran, K.P. and Kurade, N.P. (1996): Rabbit coccidiosis and its control: A review. World Rabbit Sci. 4: 37-41.

Dai, Y.; Liu, X.; Lju, M. and Tao, J. (2005): The life cycle and pathogenicity of coccidium Eimeria nocens (Kotlan, 1933) in domestic goslings. J. Parasitol. 91, 1122-1125.

EL-Masry, N.M.M. (1983): Problems of Coccidiosis In Rabbits. Thesis (M.SC.) Faculty of Veterinary Medicine - Zagazig University.

El-Shahawi, G.A.; El-Fayomi, H.M. and AbdelHaleem, H.M. (2012): Coccidiosis of domestic rabbit (Oryctolagus cuniculus) in Egypt: light microscopic study, Parasitology research, 110 (1): 251-258.

Erdogmus, Z.S. and Eroksuz, Y. (2006): DS hepatic coccidiosis in Angora rabbits. Journal of Animal and Veterinary Advances 5(6): 462463.

Grès, V.; Voza, T.; Chabaud, A. and Landau, I. (2003): Coccidiosis of the wild rabbit (Oryctolagus cuniculus) in France. Parasite, 10(1): 51-57.
Hammond, D.M. (1973): Life cycles and development of Eimeria, Isospora, Toxoplasma and related genera. In: Long, P.L. (Ed.), University Park Press, Baltimore, pp. 45-80.

Hassan, K.M.; Arafa, W.M.; Mousa, W.M.; Shokier, K.A.; Shany, S.A. and Aboelhadid, S.M. (2016): Molecular diagnosis of Eimeria stiedae in hepatic tissue of experimentally infected rabbits. Experimental Parasitology, 169: $1-5$

Heker, M.M.; Nakamura, A.A.; Santana, B.N. and Meireles, M.V. (2017): Etiological aspects of Eimeria spp. infection in Brazilian rabbit (Oryctolagus cuniculus) farms, Veterinary Parasitology: Regional Studies and Reports, (8): 78-81.

Hussein, F.N. (2008): Anasthesia and Euthanasia in Laboratory Animals. Workshop on the Care and Use of Lab An Res. Collaboration Fac.Vet. Med Airlangga Univ. and Fac.Vet. Med. UPM. Surabaya.

Ibrahim, O.I.A. (1990): Some morphological studies on the internal parasites of rabbits in Giza Governate. Thesis (M.SC.) Faculty of Veterinary Medicine Cairo University.

Jing, F.; Yin, G.; Liu, X.; Suo, X. and Qin, Y. (2012): Large-scale survey of the prevalence of Eimeria infections in domestic rabbits in China. Parasitology research, 110(4): 14951500 .

Khider, A.T.; H. Al-Rubaie, M.A. and Khalil, F.J. (2015): Prevalence of coccidiosis in local breed rabbits (Oryctolagus cuniculus) in Baghdad province. AL-Qadisiya Journal of Vet. Med. Sci. 14 (1): 15-21.

Kiernan, J.A. (2001): Histological and Histochemical Methods. 3rd Edition. Toronto: Arnold Pub. pp. 330-354.

Kvičerová, J.; Pakandl, M. and Hypša, V. (2008): Phylogenetic relationships among Eimeria spp. (Apicomplexa, Eimeriidae) infecting rabbits: evolutionary significance of biological and morphological features. Parasitology, 135: 443-452.

Laha, R.; Das, M. and Goswami, A. (2015): Coccidiosis in rabbits in a subtropical hilly region. Indian J. Anim. Res, 49(2): 231-233.

Lebas, F.; Coudert, P. and De Rochambeau, H. (1997): The Rabbit: Husbandry, Health and Production, FAO Animal Production and Health Series, 21.

Levine, N.D. (1985): Apicomplexa- the coccidia proper. In: Veterinary Protozoology, 130e138, 178. Iowa State University Press, Ames, Iowa, pp. 171-222.

Li, M.H. and Ooi, H.K. (2009): Fecal occult blood manifestation of intestinal Eimeria spp. Infection in rabbit. Vet. Parasitol. 161 (3-4): 327-329. 
Mehlhorn, H. (2006): Morphology. In: Mehlhorn, H. (Ed.), Parasitology in Focus, Facts and Trends, third ed. Springer, Berlin.

Metwaly, M.S.; Dkhil, M.A.; Gewik, M.M.; AlGhamdy, A.O. and Al-Quraishy, S. (2013): Induced metabolic disturbance and growth depression in rabbits infected with Eimeria coecicola. Parasitology Research 112(9): 3109-3114.

Ming-Hsien, L.; Hai-I, H. and Hong-Kean, O. (2010): Prevalence, infectivity and oocyst sporulation time of rabbit coccidian in Taiwan. Trop. Biomed., 27 (3): 424-429.

Mohammed, H.A.; Eid, A.A. and El-Bakrey, R.M. (2013): A review of rabbit diseases in Egypt. WARTAZOA. Indonesian Bulletin of Animal and Veterinary Sciences, 23(4): 185194.

Okumu, P.O.; Gathumbi, P.K.; Karanja, D.N.; Mande, J.D.; Wanyoike, M.M.; Gachuiri, C.K.; Kiarie, N.; Mwanza, R.N. and Borter, D.K. (2014): Prevalence, pathology and risk factors for coccidiosis in domestic rabbits (Oryctolagus cuniculus) in selected regions in Kenya. Veterinary Quarterly, 34(4): 205-210.

Oliveira, U.C.; Fraga, J.S.; Licois, D.; Pakandl, M. and Gruber, A. (2011): Development of molecular assays for the identification of the 11 Eimeria species of the domestic rabbit (Oryctolagus cuniculus). Vet. Parasitol. 176 (2-3): 275-280.

Pakandl, M. (2009): Coccidia of rabbit: a review, Folia Parasitol. 56: 153-166.

Pakes, S.P. and Gerrity, L.W. (1994): Protozoal diseases, p. 205-229. In P. J. Manning, D. H. Ringler, and C. E. Newcomer (ed.). The biology of the laboratory rabbit, 2nd ed. Academic Press, Inc., San Diego, Calif

Qiao, J.; Meng, Q.L.; Cai, X.P.; Tian, G.F.; Chen, C.F.; Wang, J.W.; Wang, W.S.; Zhang, Z.C.; Cai, K.J. and Yang, L.H. (2012): Prevalence of Coccidiosis in domestic rabbits (Oryctolagus cuniculus) in Northwest China. J. Anim. Vet. Adv., 11(4): 517-520.

Ragheb, R.R.; Saad, A.E. and Tanios, A.I. (1999): Some studies on enteritis in rabbits. Egypt J. Agric. Res., 77:18-47.

Razavi, S.M.; Oryan, A.; Rakhshandehroo, E.; Moshiri, A. and Mootabi Alavi, A. (2010): Eimeria species in wild rabbits (Oryctolagus cuniculus) in Fars province, Iran. Trop. Biomed, 27: 470-475.

Shi, T.; Tao, G.; Bao, G.; Suo, J.; Hao, L.; Fu, Y. and Suo, X. (2016): Stable Transfection of Eimeria intestinalis and Investigation of Its Life Cycle, Reproduction and Immunogenicity. Front. Microbiol. 7:807.

Smetena, H. (1933): Coccidiosis of the liver of rabbits: experimental study of the mode of infection of the liver by sporozoites. Arch. Pathol. 15, 330-339.

Song, H.Y.; Zhu, S.X.; Liu, C. and Shao, Y.X. (2012): A survey of Eimeria infections in experimental rabbits in Jiangsu Province. Progress Vet. Med. 33 (12): 88-91.

Soulsby, E.J.L. (1982): Helminths, Arthropods, and Protozoas of Domestic Animals. 7th Ed., Bailliere, Tindall and Cassell, London, pp. 676-682.

Szkucik, K.; Pyz-Lukasik, R.; Szczepaniak, K.O. and Paszkiewicz, W. (2014): Occurrence of gastrointestinal parasites in slaughter rabbits. Parasitol Res 113(1):59-64.

Tao, G.; Wang, Y.; Li, C.; Gu, X.; Cui, P.; Fang, S.; Suo, X. and Liu, X. (2017): High pathogenicity and strong immunogenicity of a Chinese isolate of Eimeria magna Pérard, 1925, Parasitol Int. 66: 207-209.

Toula, F.H. and Ramadan, H.H. (1998): Studies on coccidia species of genus Eimeria from domestic rabbit (Oryctolagus cuniculus domesticus L.) in Jeddah, Saudi Arabia. J Egypt Soc Parasitol., 28(3):691-698.

Vancraeynest, D.D.; Gussem, M.; Marien, M. and Maertens, L. (2008): The anticoccidial efficacy of robenidine hydrochloride in Eimeria challenge rabbits. In: Pathology and Hygiene, 9th World Rabbit Congress, Verona, Italy, pp. 1103-1106.

Wessels, J.; Wessels, M.E.; Wood, R. and Quayle, J. (2011): Hepatic coccidiosis in red lechwe (Kobus leche leche). Vet. Record, 168:338.

Yakhchali, M. and Tehrani, A. (2007): Eimeriidosis and pathological findings in New Zealand white rabbits. J. Biol. Sci., 7(8): 1488- 1491.

Yan, W.; Wang, W.; Wang, T.; Suo, X.; Qian, W.; Wang, S. and Fan, D. (2013): Simultaneous identification of three highly pathogenic Eimeria species in rabbits using a multiplex PCR diagnostic assay based on ITS1-5.8S rRNA-ITS2 fragments. Vet. Parasitol. 193 (1e3): 284-288.

Yin, G.; Goraya, M.U.; Huang, J.; Suo, X.; Huang, Z. and Liu, X. (2016): Survey of coccidial infection of rabbits in Sichuan Province, Southwest China. Springer Plus, 5(1): 870. 


\section{دراسات باثولوجية وطفيلية على بعض انواع الايمريا فى الارانب باستخدام الميكروسكوب الضوئى والإكترونى}

\section{عبير هاشم مصطفى الهندى ، هدى محمد محمد قراعه ، باسم رفعت نـبيب}

E-mail: Abeerhashim_elhendy@yahoo.com; Huda5380@yahoo.com; Basemnageib@gmail.com Assiut University web-site: www.aun.edu.eg

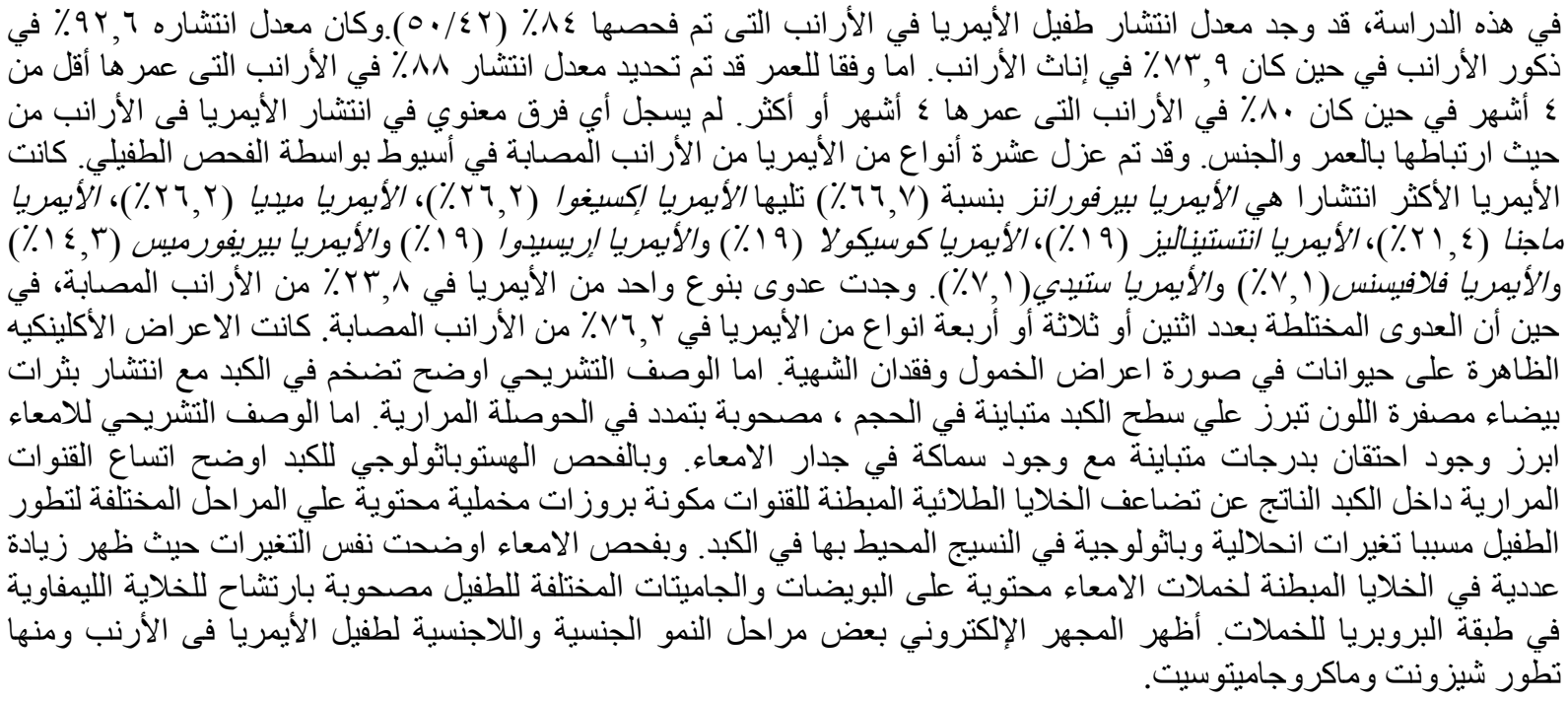

